\title{
Elevation of optics and photonics education in Thailand
}

\section{Suwannee Phoojaruenchanachai, Sarun Sumriddetchkajorn}

Suwannee Phoojaruenchanachai, Sarun Sumriddetchkajorn, "Elevation of optics and photonics education in Thailand," Proc. SPIE 9666, 11th Education and Training in Optics and Photonics Conference, 96660E (5 June 2009); doi: $10.1117 / 12.2208029$

SPIE Event: Eleventh International Topical Meeting on Education and Training in Optics and Photonics, 2009, St. Asaph, United Kingdom 


\title{
Elevation of Optics and Photonics Education in Thailand
}

\author{
Suwannee Phoojaruenchanachai ${ }^{*}$ and Sarun Sumriddetchkajorn \\ Photonics Technology Laboratory (PTL), \\ National Electronics and Computer Technology Center (NECTEC) \\ National Science and Technology Development Agency (NSTDA) \\ 112 Thailand Science Park, Phahonyothin Rd., Klong 1, \\ Klong Luang, Pathumthani 12120, THAILAND \\ Phone: (66-2) 564-6900 ext. 2106, Fax: (66-2) 564-6774
}

\begin{abstract}
We initiate a pilot project of photonics education outreach to Thai society in order to heighten public awareness and to inspire new generations of science and technology in photonics. Our target groups are students, teachers and public people. In our first state, we focus on students and teachers especially in the rural area. Learning-by-playing and critical-thinking-by-doing approaches are selected to nurture and reinforce students. For secondary and high school students, we provide a two-hour seminar on applications of photonics in daily life in order to motivate them to do science or engineering projects related to photonics. Specifically, our technical workshop with hands-on experiments provides a practical way for teachers to inspire their students about optics and photonics. Based on our phase I work with 1044 students from 21 primary schools, we find that $90 \%$ of them have fun and gain new asset in photonics. With our approach for secondary and high school levels, there are three projects accepted for the first round in the 2009 Young Scientist Competition. In addition, $90 \%$ of 85 teachers from 59 schools recognize and understand more about optics and photonics. In our further work, we will focus on the involvement of public people in order to create a new momentum that fulfills our mission.
\end{abstract}

\section{KEYWORDS}

Photonics outreach, Optics outreach programs, Photonics public awareness, Learning-by-playing, Inquiry-Based Process, Critical thinking, Shining-Spectrum-to-Society.

\section{INTRODUCTION}

With the growth of science and technology (S\&T) in the $21^{\text {st }}$ century, Optics and Photonics (OP) has been a key player in today and future applications ranging from flat panel displays, green IT, and silicon photonics. However, OP was previously viewed as an orphan discipline because it worked behind the scene in order to make electronic systems operate effectively. This issue also leads people not to realize how OP

\footnotetext{
E-mail: suwannee.phoojaruenchanachai@nectec.or.th
} 
impacts our everyday life and do not have motivation to learn more about it. If we consider the science core theme $^{1}$ in our educational system, OP is not even emphasized and therefore our industrial sector and community lack qualified engineers and researchers who can solve specific technical issues in the production line as well as who can come up with innovative ideas and products. Hence, dissemination of OP to our community is needed.

In 2008, we established a project called "Shining Spectrum to Society ${ }^{2}$ (SSS) in which we aimed to promote public awareness especially new generations to understand more about OP and its applications in everyday life through the combination of a hands-on teaching approach and media engineering. We also encouraged students in high schools to utilize their knowledge, learn new things, and practice their skill in order to do their science or engineering projects related to OP. Since then, several activities have been in active and some are on the way. In this paper, we summarize our Phase I achievements in motivating students and sharing skill and processes with teachers.

\section{TARGETS AND STRATEGIES}

\subsection{Target Groups}

OP Education in Thailand has been concerned by a few small groups of people who teach ${ }^{3}$ or work $^{4-7}$ in OP. Therefore, it has gradually grown until the shortage of human resources qualified in this field occurs in the current industrial situation and probably for the future. To alleviate this problem at its first cause, we need to setup a proper strategy and determine the target groups in order to elevate OP education in Thailand to another level. Our target groups are students, teachers, and general publics as shown in Figure 1. The first two groups directly relate to how OP education can be accomplished while the last group plays a significant role in influencing $\mathrm{OP}$ in the Thai community.

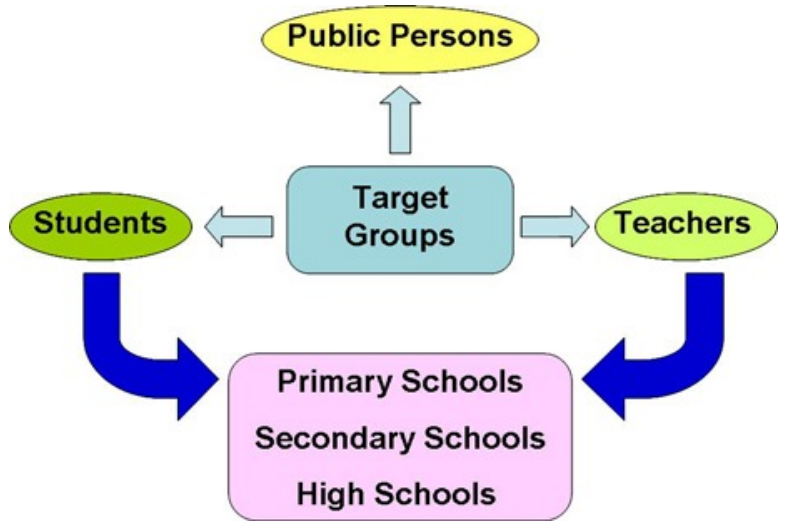

Figure 1. Our target groups in elevating OP education in Thailand.

\section{- Students}

For Thailand, OP definition and knowledge as well as its applications have been imperative in mind only for undergraduate and graduate students who have made contributions and have gained some experiences when they are in some universities. In the contrary, primary and secondary school students have been disregarded as the minor groups for OP learning even though they are really our new generations for our country's development in the foreseeable future. Hence, we need to start nurturing and reinforcing them in the awareness of OP. For high schools students, we have to open their minds as well as to prepare their practical point of view and needed skill for learning basic and advanced OP issues. 


\section{- Teachers}

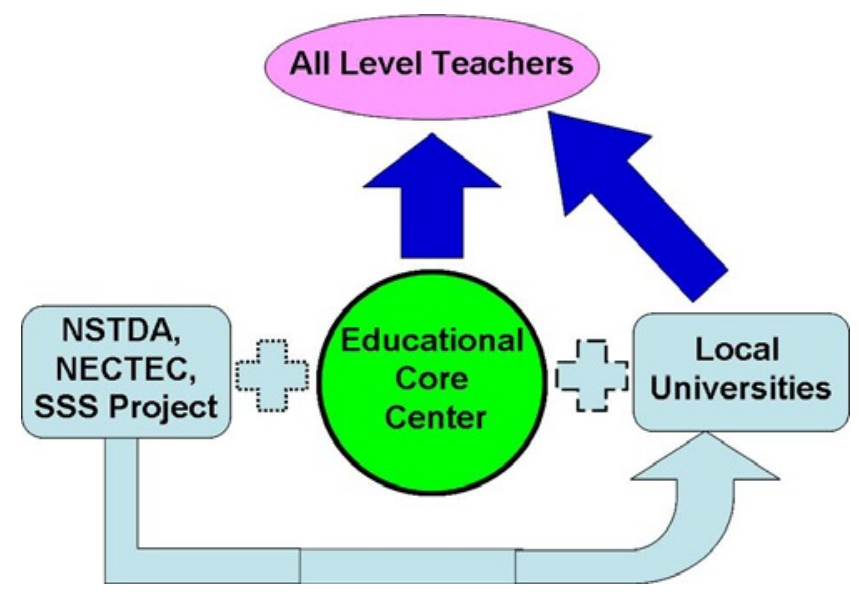

Figure 2. Our expected incorporation among teachers, local universities, and us.

Teachers are the master model of the students apart from their families. However, most science teachers in the primary and secondary schools lack proper skill and processes in teaching science. They sometimes teach science via memorizing instead of trying to engage and encourage students to learn science via scientific thinking and critical thinking processes. In addition, lack of interesting demonstrations or educational kits for teaching and hands-on learning is a key factor in making science more interesting in the class. With these issues in mind, teachers trained in OP and low-cost educational kits are needed. Figure 2 shows our scheme that networks our research institute with local universities and educational core centers in order to strengthen teachers in all levels about OP.

\section{- Public Persons}

Apart from teachers and students, if public people understand more about OP and its impact in everyday activity, they will play a really significant role in creating a momentum that retro-reflects to leverage OP education in Thailand to the desired level.

\subsection{Strategies}

- For elementary and primary school students: we exploit our learning-by-playing approach. We also utilize our photonics kit in the process of building the critical thinking about daily OP.

- For secondary and high school levels: we give students in these two levels a two-hour seminar on applications of photonics in daily life in order to motivate them to do science or engineering projects related to photonics. Soft and hard media are also included during the seminar ${ }^{8}$.

- For teacher: we develop an easy-to-use photonics kit using simple tools for demonstrations. We incorporate closely with the local universities to provide one day of seminar and workshop for sharing knowledge in OP and exchange ideas especially our approach for effectively teaching OP via our educational kit. 
- For general publics: we join several groups from NECTEC and NSTDA to demonstrate our photonics kit in several occasions. These include two festivals held during the National Science Day and the National Children's Day.

\section{PRIMARY ACHIEVEMENTS AND BARRIERS}

In our first state, we visit 21 primary schools in every part of Thailand. Most schools involved in our activity not only their OP education stay behind others but also their budget in leveraging the quality of their education system is low. A total number of students participated in our activity is 1044 covering 1020 in the grade four to six and 24 in the secondary level. For the high school level, we give our two-hour seminar to 1078 students from 11 schools in every part of Thailand (see Figure 3).

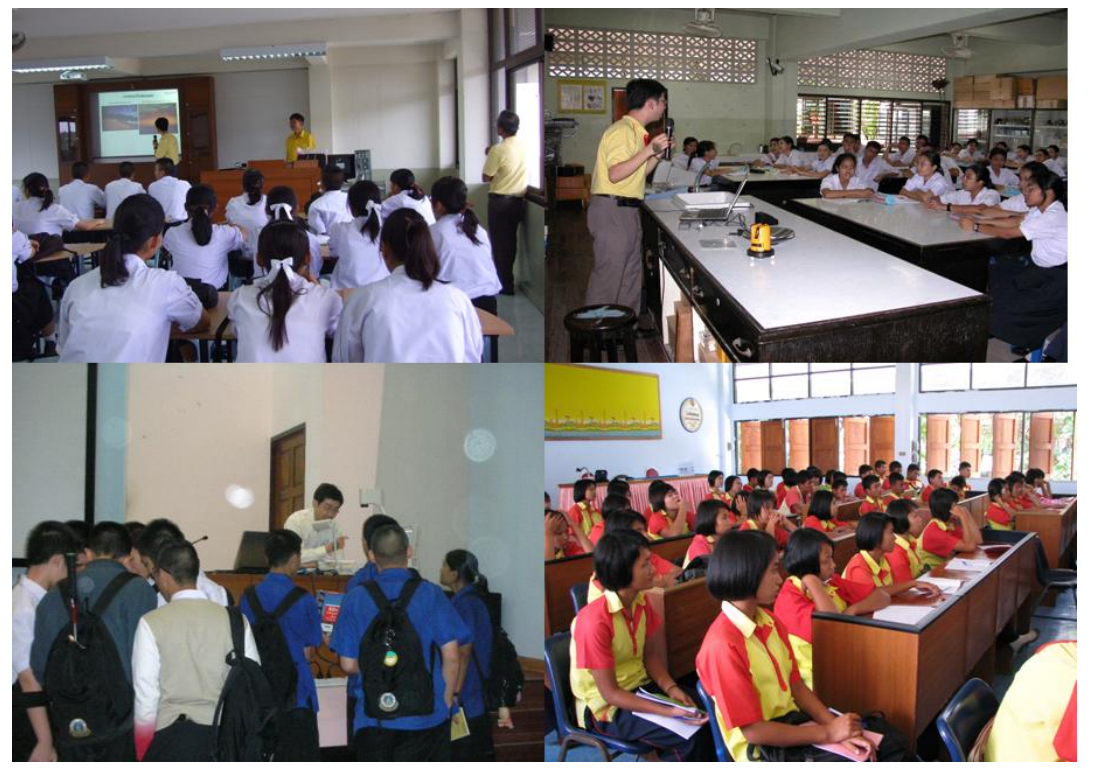

Figure 3. Our activities with high school students

In addition, we have networked with three local Rajabhat universities in Phuket, ChaingRai, and Surindra provinces to give a workshop and a seminar to 129 teachers as shown in Figure 4.

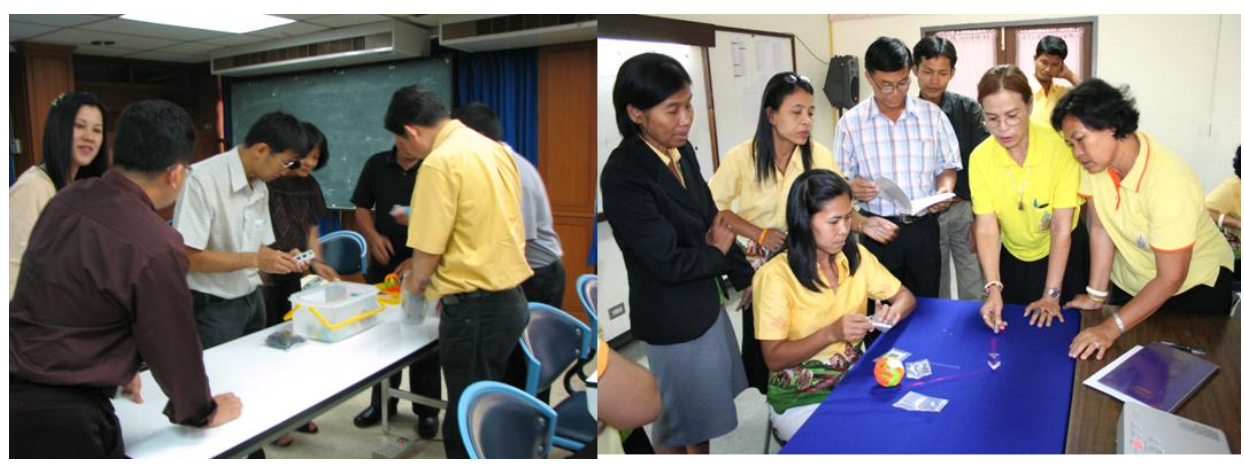

(a) 


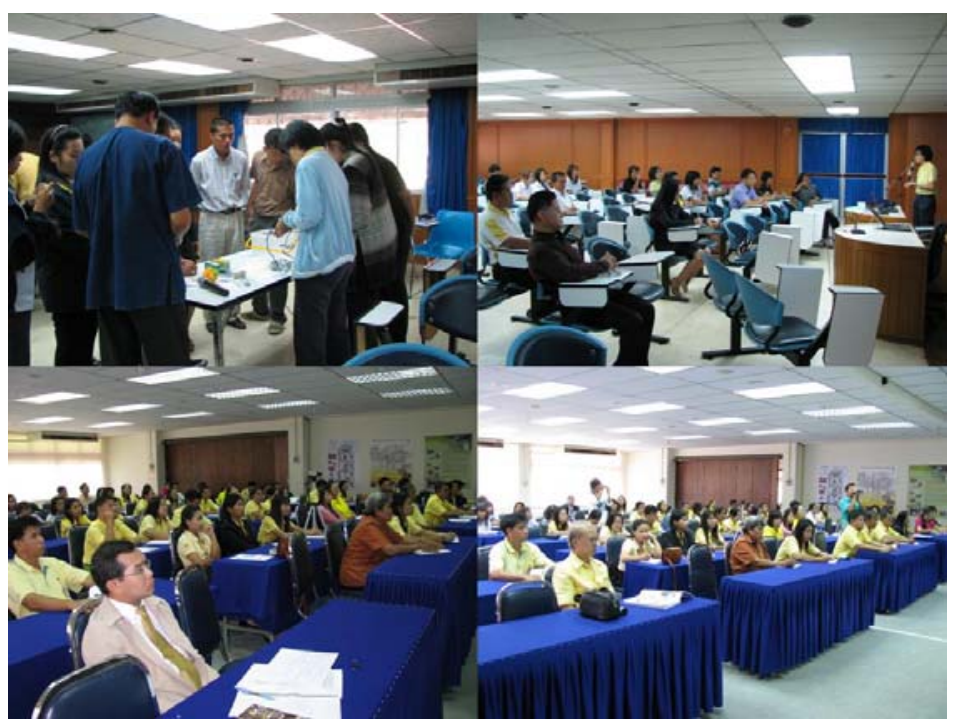

(b)

Figure 4. Our (a) workshop and (b) seminar for teachers.

\subsection{Primary successes}

More than $90 \%$ of primary and secondary students have fun playing with our educational kit (see Figure 5) and understand more about OP in daily life. One year after our visit, we receive the information from one school in Payao province that $50 \%$ of participated students are planning to study in a science and mathematics program. They are specifically interested in the OP program for their future study in the undergraduate level. For high school students, there are three projects accepted for the first round in the 2009 Young Scientist Competition. Note that these three projects are from the school where the project is assigned as one of the core courses.

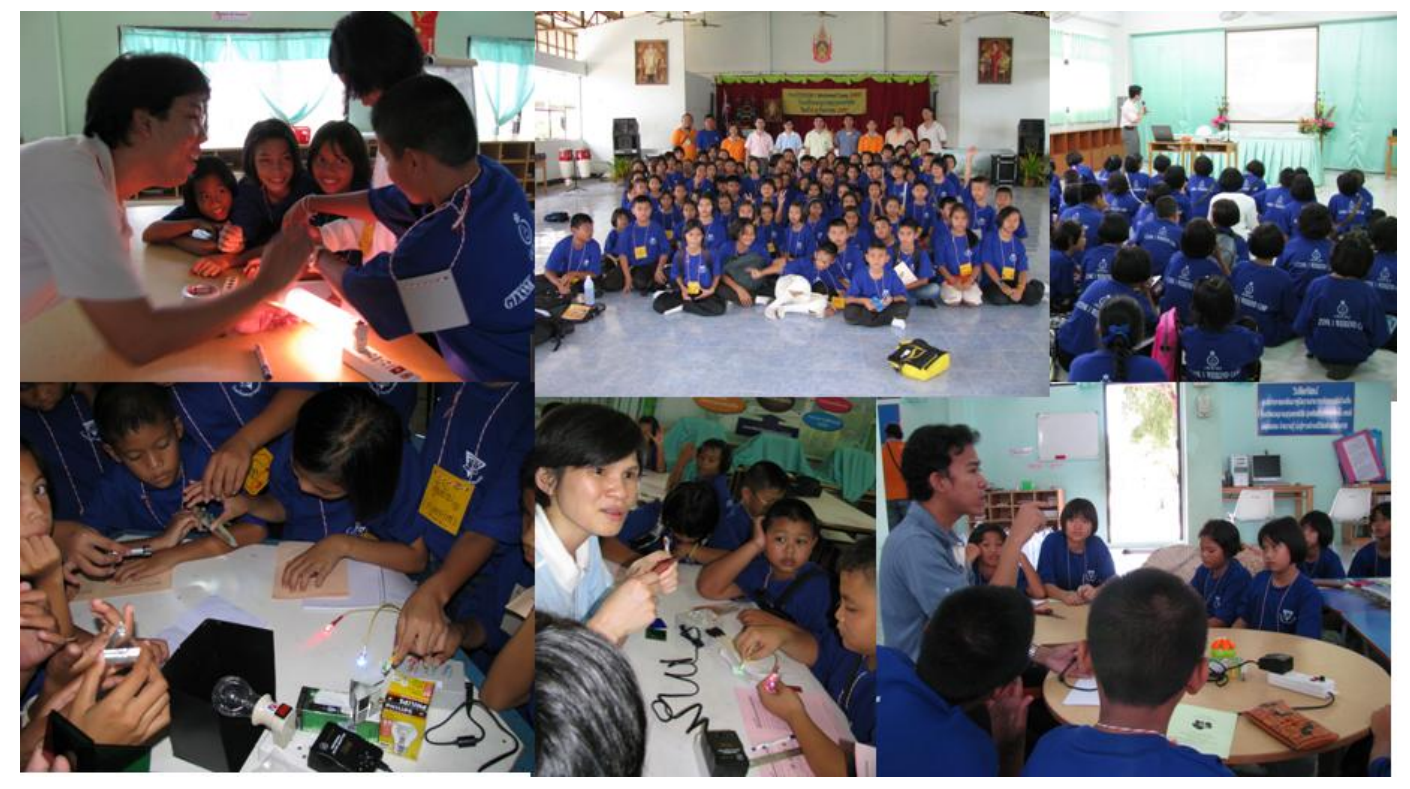

Figure 5. Our activities with primary school students. 
For teachers, $90 \%$ of 85 teachers from 59 schools recognize and understand more about optics and photonics. Most teachers appreciate our workshop and they are interested in our developed photonics kit. Note that only 85 of 129 teachers sent us their feedbacks.

\subsection{Barriers}

Based on our activities delivered to students, teachers, and general publics, they now realize and understand more about the impact of OP for our country's sustainability and competency. However, there is a barrier that delays steps to improve S\&T education system in Thailand. Especially, we find that policy makers in the education are not seriously taking into consideration the OP. To alleviate this problem, we steer to general publics and local media. If they realize the importance of S\&T, in particular to OP, they will help us to promote OP to our society. \#ith this approach in mind, we join two national social festivals such as the National Children's Day and the National Science Day\#o demonstrate OP (see Figure 6). A correspondent from Manager Newspaper, one of the local newspapers, comes to interview us about our activities and goals.

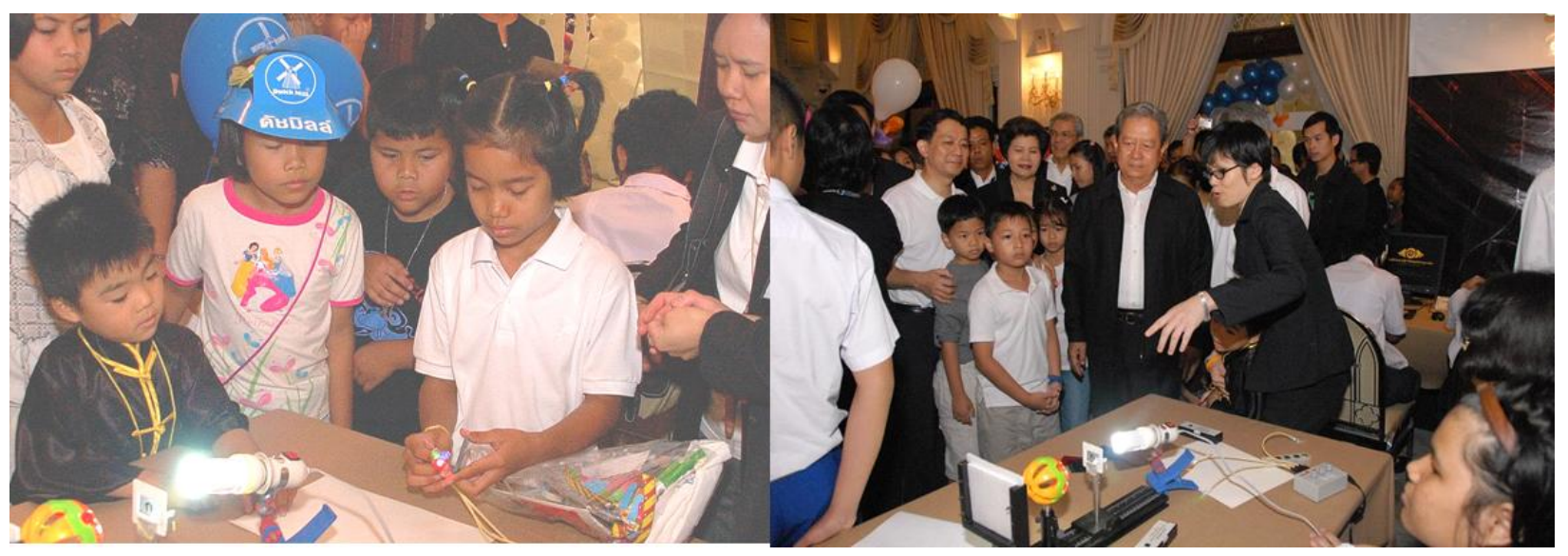

Figure 6. Our activities shown during the National Children's Day at Royal Thai Government.

\section{CONCLUSIONS}

Our Phase I work can effectively inspire a group of primary students from 21 schools. We find that $90 \%$ of them have fun and gain new knowledge in OP. With our approach for secondary and high school levels, there are three projects accepted for the first round in the 2009 Young Scientist Competition. In addition, $90 \%$ of 85 teachers from 59 schools recognize and understand more about optics and photonics. Our further work will focus on getting the involvement from the public people in order to create a new momentum that fulfills our mission.

\section{ACKNOWLEDGMENTS}

Authors would like to thank NSTDA, SPIE, OSA and IEEE-LEOS for financial support. We are indebted to Asst. Prof. Penpan Ganpinyo from Chaingrai Rajabhat University for her assistant in association with the local teachers attending to our workshop in OP. We are grateful to Asst. Prof. Sopa Simarugumpai from Surindra Rajabhat University for her assitant in contact with the teachers in Surindra and neighborhood. Special thanks to all PTL members for their contribution to valuable discussions. 


\section{REFERENCES}

[1] Ministry of Education, Basic Educational Core Curriculum, (2008). (Thai language)

[2] Sumriddetchkajorn, S. and Phoojaruenchanachai, S., "Shining-Spectrum-to-Society Project: A project for diffusing photonics education in Thailand," Proc. the $3^{\text {rd }}$ National Conference on Optics and Application, pp.5-9, Bangkok, Thailand, August 15, (2008). (Invited paper)

[3] Wongtawatnugool, C., Ngamjarurojana, A., and Lacharojana S., "Light work at Chiang Mai University, Thailand," SPIE Proceeding of ETOP 2001, Vol. 4588, pp.41-49, Singapore, 26-30 November, (2001)

[4] Phoojaruenchanachai, S. and Chaitavon, K. "An educational kit for studying reflection and refraction light," Proc. the $27^{\text {th }}$ Congress on Science and Technology of Thailand, pp.780, Songkla, Thailand, October 16-18, (2001). (Thai language)

[5] Sumriddetchkajorn, S., Photonics...the miracle of light, NanmeeBooks, February 2006. (Thai language)

[6] Phoojaruenchanachai, S. and Sumriddetchkajorn, S. "Long Len photonics kit," Proc the $18^{\text {th }}$ Congress on Science and Mathematic Education in School, pp.94, Nakhon Pathom, Thailand, March 26-28, (2008). (Thai language)

[7] Phoojaruenchanachai, S. and Sumriddetchkajorn, S., Long Len with Light, NanmeeBooks, (2009). (Thai language, publication processing)

[8] Sumriddetchkajorn, S. and Phoojaruenchanachai, S. "Have fun with optics through hands-on and media engineering approaches," Proc. the $4^{\text {th }}$ National Conference on Optics and Applications, Chonburi, Thailand, Feb. 2009. \#nvited paper)

[9] Tang, Jinfa and Lu, Zukang, "Progress in education of optical engineering in China," SPIE Proceeding of ETOP 1991, Vol. 1603, pp. 32-40, Leningrad (St.Petersburg), USSR, 28 September-1 October, (1991). (Invited paper)

[10] Unlu, M. S., Ruane, M. F., Goldberg, B. B., Moustaks, T. D., Saleh, B. E. A., and Teich, M. C., "PRIDE: Photonics Research in Interdisciplinary Education," ASEE Annual Conference Proceedings, Session 1626, (1996).

[11] Osin ski, M., Prasad, S., Guenther, A. H., Madsen, A. L., and McCormick, C. B., "Curriculum, program, and infrastructure development for Bachelor of Science in Optical Science and Engineering," Proc. ETOP 2003, No.EWD2, pp. 220-234, Tucson, Arizona (USA), 6-9 October, (2003). (Invited paper)

[12] Jonathan, E., "Optics education in a developing country," Proc. ETOP 2005, No. 013, pp. 46-53, Marseille, France, 24-27 October, (2005).

[13] Costa, Manuel F. M., "Optics in a changing education," Proc. ETOP 2005, No. 011, pp. 39-41, Marseille, France, October 24-27, (2005).

[14] Rosberg, C. R, Fischer, R. and Prasad, A., "Long-distance learning: teaching optics in the outback," Optics \& Photonics News, Vol.18, No.6, pp.22-23, (2007).

[15] Jacobs, S.D., Gregg, L. L., Andrews C. M., and R. L. Coppens, "Optics suitcase: educational outreach presentation guide," Posted online: http://www.opticsexcellence.org, Accessed on December (2008).

[16] John, P., Wilcox, K., and Patel, S., "The light express roadshow: a case study in a successful secondary school's photonics outreach activity," Proc. ETOP 2005, No.048, pp. 184-186, Marseille, France, 24-27 October, (2005).

[17] Lakhdar, Z. Ben and et al, "Active learning in physics a way for rational thinking - A way for development," Proc. ETOP 2007, pp. 11-16, Ottawa, Canada, June 3-5, (2007).

[18] Costa, Manuel F. M., Sporea, D., and Clementina, Timus, C. A., "Optics education in the frame of the Comenius "hands-on science" project," Proc. ETOP 2005, No.107, pp. 413-414, Marseille, France, 2427 October, (2005).

[19] Magnani, N. and Donnelly, J., "Innovative methods to teach optics in the grade 5 classroom," Proc. ETOP 2007, pp. 151-159, Ottawa, Canada, June 3-5, (2007).

[20] Takayama, O., Niederberger, A., Ghenuche, P., Mathew, M., and Volpe, G., "El dia de la luz (the day of light)-two hours optics demonstration for secondary school students," Proc. ETOP 2007, pp. 160-165, Ottawa, Canada, June 3-5, (2007).

[21] Mccarthy, J. and Moore, R.A., "Maximum impact flow for optics teaching," Proc. ETOP 2005, No. 003, pp. 10-12, Marseille, France, 24-27 October, (2005).

[22] Guzik, R. P., "A tutorial on light and optics for grade school teachers," Optics \& Photonics News, Vol.15, No.6, pp.18-21, (2004). 
[23] Lones, J. J., Maltseva, N. K. and Peterson, K. N., "Science and fun in a "magic show of light" from optical demonstrations on an overhead projector for elementary school student," Proc. ETOP 2007, pp. 429-434, Ottawa, Canada, June 3-5, (2007).

[24] Clark, J. H. and Gilchrist, P. O., "Photonics xplorers and leaders: challenging diverse students in a flat world for emerging careers," Proc. ETOP 2007, pp. 116-126, Ottawa, Canada, June 3-5, (2007).

[25] Massa, N., Audet, R., Donnelly, J., Hanes, F., and Kehrhahn M., "PHOTON PBL: Problem-Based Learning in photonics technology education," Proc. ETOP 2007, pp. 329-337, Ottawa, Canada, June 3-5, (2007).

[26] Brecher, K., "Project LITE: Light Inquiry Through Experiments," Proc. ETOP 2007, pp. 166-174, Ottawa, Canada, June 3-5, (2007).

[27] Dyomin, V. V. and Polovtsev, I. G., "Educational kit for optical experiments," Proc. ETOP 2007, pp. 310320, Ottawa, Canada, June 3-5, (2007).

[28] Kruglak, H. "The compact disc as a diffraction grating," Physics Education, Vol.26, No.4, pp.255-256, (1991).

[29] Varshneya, R. and DeGroote, J., "An encounter with optics for grade school students," Optics \& Photonics News, vol.15, No.11, pp.16-17, (2004).

[30] http://www.gammaco.com/gammaco/product_list.php?id=PHYSICS, Accessed on June 13, (2008).

[31] http://www.exploratorium.edu/snacks/bridge_light/index.html, Accessed on October 27, (2006).

[32] http://www.hands-on-optics.org/home, Accessed on January, (2007). 